\title{
ANALISIS ORIENTASI PASAR DAN STRATEGI BAURAN PEMASARAN PENGUSAHA ROTI DI KOTA BENGKULU
}

\section{ANALYSIS OF MARKET ORIENTATION AND MARKETING MIX STRATEGIES OF BAKERY ENTREPRENEURS IN BENGKULU}

\author{
Gracia Gabrienda, Nusril, dan Redy Badrudin \\ Jurusan Sosial Ekonomi Pertanian Fakultas Pertanian Universitas Bengkulu
}

\begin{abstract}
This research is aimed at investigating market posisition and market orientation of bakery producers, and designing mix marketing strategy for bakery producers in Bengkulu city. Four bakery producers, namely Surya Bakery, Bake Mart, Karina Bakery and Ais Bakery, are selected purposively as subject of this study. Sixty eight respondents are selected using accidental sampling method for UAI survey, and 4 respondents for each bakery. Relative Market Share and descriptive analysis are used to analyse data obtained from survay. The research found that Surya Bakery can be categorised as market leader, while Bake Mart, Karina Bakery, and Ais Bakery as market challanger, market follower, and market nicher respectively. All bakery producers has custumer orientation. The study also concluded that Surya Bakery should enlarge its market and intisifies promotion, Bake Mart should enlarge its distribution network, Karina Bakery should expose its specific shop and Ais Bakery should find new market segment.
\end{abstract}

Keywords: Market Orientation, Marketing mix, Bread enterpreneur

\section{PENDAHULUAN}

Secara struktural laju perekonomian Provinsi Bengkulu masih didominasi pada sektor pertanian. Dari data Pertumbuhan Domestik Regional Bruto (PDRB) triwulan III 2007 yang dikeluarkan Badan Pusat Statistik (BPS) Provinsi Bengkulu atas dasar konstan sektor ini menyumbang sebesar Rp. $725 \mathrm{M}$ atau sekitar 40\% dari total PDRB harga konstan sebesar Rp. 1,8 T (BPS, 2008). Dari segi daya serap kerja. Sektor pertanian pada tahun 2006 mampu menyerap tenaga kerja dengan proporsi yang hampir 70 persen atau tepatnya $69,9 \%$. Sedangkan pekerja yang terserap disektor lain seperti perdagangan dan jasa-jasa relatif rendah masing-masing sebesar 11,5 persen dan sebesar 9,6 persen (BPS, 2008). 
Industri dapat ditingkatkan dengan adanya wawasan yang baik mengenai industri yang akan dikembangkan. Disamping memberikan lapangan kerja, industri juga sebagai lapangan usaha yang bersifat kompetitif. Salah satu industri yang berkembang di kota Bengkulu adalah industri makanan ringan, yang sedang berkembang saat ini adalah usaha pembuatan roti (Irawan, 2005).

Roti adalah sejenis makanan, bahan dasar utama roti adalah tepung dan air yang difermentasikan oleh ragi, tetapi ada juga yang tidak menggunakan ragi. Namun dengan kemajuan teknologi saat ini, membuat roti kini diolah dengan berbagai bahan seperti garam, minyak, mentega, ataupun telur untuk menambahkan kadar protein di dalamnya sehingga didapat tekstur dan rasa tertentu (Anonim, 2011). Makanan ini sudah menjadi salah satu makanan pokok bagi masyarakat Indonesia. Bahkan di kalangan remaja dan anak-anak, posisi makanan itu telah mulai menggeser nasi sebagai sumber karbohidrat utama. Jenis roti yang beredar saat ini sangat beragam. Secara umum roti biasanya dibedakan menjadi roti tawar dan roti manis atau roti isi (Anonim, 2009)

Di Kota Bengkulu mulai banyak orang mengusahakan membuat roti dan membuka toko roti. Hal ini karena peminat roti semakin bertambah setiap harinya. Biasanya roti dibeli untuk acara-acara arisan, seminar-seminar, menyambut hari raya, dan konsumsi sehari-hari. Inilah yang menjadi alasan mengapa usaha roti ini banyak diusahakan oleh banyak orang. Semakin banyaknya pengusaha roti yang ada di kota Bengkulu ini dikarenakan masyarakat juga ingin mengembangkan usaha yang cukup menggiurkan ini, bukan hanya karena alasan ikut-ikutan saja. Dampak dari banyaknya pengusaha roti di kota Bengkulu ini adalah semakin banyak tenaga kerja yang dipergunakan, sehingga mengurangi tingkat pengangguran yang ada di kota Bengkulu. Kemudian pembeli akan lebih banyak pilihan dalam memilih roti untuk dibeli.

Pihak pengusaha-pengusaha roti ini harus mengembangkan berbagai strategi pemasaran dalam menunjang penjualan yang nantinya akan mendukung terhadap kelangsungan perkembangan usaha yang lebih baik lagi. Menurut Winardi (1981) salah satu strategi yang harus dikembangkan dalam mengembangkan usaha adalah dengan memahami $4 \mathrm{P}$, yakni produk, harga, distribusi dan promosi, untuk dapat mengambil langkah-langkah yang harus diambil pengusaha roti agar produk yang ditawarkan dapat diterima oleh konsumen.

Penelitian ini bertujuan untuk : 1) mengetahui posisi pasar produsenprodusen roti di Kota Bengkulu. 2) mengkaji orientasi pasar yang dilakukan produsen-produsen roti yang ada di Kota Bengkulu, dan 3) menyusun formulasi strategi bauran pemasaran yang dilakukan produsen-produsen roti di Kota Bengkulu. 


\section{METODE PENELITIAN}

\section{Pengumpulan Data}

Objek dalam penelitian ini adalah pengusaha dan konsumen roti yang berlokasi di Kota Bengkulu. Penentuan objek dan lokasi penelitian ini dilakukan secara sengaja (purposive). Pemilihan kota Bengkulu menjadi lokasi penelitian dengan alasan kota Bengkulu merupakan daerah yang banyak pengusaha dan konsumen rotinya bila dibandingkan dengan daerah-daerah lainnya di provinsi Bengkulu.

Konsumen roti yang berlokasi di Kota Bengkulu dipilih untuk mengetahui gambaran sikap/preferensi konsumen di Kota Bengkulu terhadap bauran pemasaran pengusaha-pengusaha roti, dengan pertimbangan bahwa Kota Bengkulu merupakan konsumen roti yang terbesar dan sentra produksi.

Penelitian ini dilakukan secara sengaja (purposive) yakni di kecamatan dan kelurahan yang telah ditentukan. Pengambilan sampel dari kecamatan dan kelurahan yang telah ditentukan ini akan melihat dari persentase orang yang telah bekerja. Sampel yang diambil yakni 68 orang untuk konsumen roti dan 4 untuk toko roti yang diteliti

\section{Metode Analisa}

Metode analisa yang digunakan untuk mengetahui serta menyusun orientasi pasar dan strategi pemasaran yang akan dilakukan oleh keempat toko roti ini, yaitu dengan menganalisa kedudukan (posisi) perusahaan di pasar persaingan, untuk mengetahui kedudukan masing-masing pengusaha roti di Kota Bengkulu dengan menggunakan tingkat peluang pasar (market share), kedudukan masing-masing perusahaan dapat dilakukan urutan atau rangkingnya dalam pasar persaingan. Perlu memilih dan menentukan perusahaan-perusahaan lain yang dianggap sebagai pesaing perusahaan. Rasio ini, dikenal sebagai Relative Market Share. Secara berturut-turut posisi perusahaan dapat dibedakan sebagai: Marker Leader, Challenger, Follower, dan Market Nicher.

Metode analisa yang digunakan untuk mengetahui orientasi pasar pengusaha roti di kota Bengkulu yakni dijelaskan secara deskritif. Analisa deskriptif digunakan untuk menjelaskan secara menyeluruh (comprehensive) data yang diperoleh. sedangkan untuk formulasi strategi bauran pemasaran. Untuk merancang atau merumuskan alternative strategi pemasaran yang yang diperlukan pengusaha roti akan dilakukan secara deskriptif dengan memanfaatkan data dari pihak pengusaha roti, UAI survey dan data sekunder. 


\section{HASIL DAN PEMBAHASAN}

\section{Karakteristik Responden}

Persentase tertinggi umur konsumen roti di Kota Bengkulu adalah dibawah umur 35 tahun dengan persentase $64,70 \%$. Pada fase ini, usia dibawah 35 tahun memiliki leinginan berbelanja atau mengkonsumsi makanan selingan lebih tinggi, biasanya dilakukan saat berkumpul bersama teman ataupun sekedar memenuhi keinginan mengkonsumsi makanan selingan yang enak dan bergizi. Pada umur ini juga menggambarkan bahwa konsumen roti di Kota Bengkulu ini tergolong masih dalam usia produktif. Hal ini merupakan pertimbangan bagi pihak pengusaha roti untuk melakukan program pemasaran yang ditujukan pada segmen umur yang produktif tersebut.

Pendidikan sangatlah mempengaruhi responden dalam hal berfikir dan bertindak termasuk mengkonsumsi kebutuhan makanan dan minuman. Pendidikan formal tertinggi yang pernah ditempuh oleh konsumen roti adalah secara keseluruhan tingkat pendidikan yang pernah ditempuh oleh konsumen roti yaitu SMP dengan 1,47\%, kemudian 30,88\% tingkat SLTA, sedangkan untuk pendidikan Diploma sebanyak 19,11\%, untuk Sarjana 47,05\% dan S2 sebanyak $1,47 \%$. Secara keseluruhan dapat diketahui bahwa pendidikan terakhir responden kebanyakan adalah Sarjana. Dengan tingkat pendidikan yang cukup tinggi tersebut, maka diharapkan penyerapan informasi tentang roti menjadi lebih mudah, sehingga pengusaha roti dapat lebih mudah melaksanakan program pemasaran yang baik dan tepat. Hasil tersebut menunjukkan bahwa sebagian besar konsumen roti sangat berpendidikan, sehingga memungkinkan konsumen untuk memiliki pola fikir yang lebih terbuka dalam memahami inovasi-inovasi baru. Hal ini pun mencerminkan bahwa tingkat pendidikan juga akan mempengaruhi perubahan-perubahan pola konsumsi rumah tangga dalam mengkonsumsi roti.

Untuk persentase pekerjaan, pekerjaan yang paling banyak dilakukan oleh konsumen roti adalah bekerja sebagai PNS (Pegawai Negeri Sipil) yakni sebanyak 32,35\%. Hal ini mungkin disebabkan PNS lebih memiliki kesempatan lebih mendapatkan informasi tentang produk roti ini, pada saat mereka mengikuti pelatihan, seminar-seminar, dan berbagai acara lainnya. Ini juga sesuai dengan metodologi yang diterapkan oleh peneliti, bahwa konsumen potensial yang membeli roti adalah orang yang telah bekerja dan memiliki penghasilan setiap bulannya, salah satunya adalah Pegawai Negeri Sipil ini.

Seiring dengan pekerjaan yang paling banyak dilakukan oleh konsumen roti yang ada di Kota Bengkulu yaitu Pegawai Negeri Sipil, penghasilan keluarga perbulan konsumen roti yang ada di Kota Bengkulu ini ialah sebanyaj $67,64 \%$ konsumen roti memiliki penghasilan keluarga perbulannya sebesar 1.000.000 rupiah hingga 3.000.000 rupiah perbulannya. Dengan penghasilan yang relatif besar, mereka juga berkesempatan memenuhi kebutuhan sekunder, seperti memenuhi keinginannya untuk melakukan pembelian produk roti. Menurut Kotler (1995) pilihan produk sangat dipengaruhi oleh keadaan 
ekonomi seseorang, keadaan ekonomi sendiri terdiri dari penghasilan yang dapat dibelanjakan (tingkat pendapatan, stabilitas dan pola waktunya, tabungan, dan kekayaan serta sikap atas belanja atau menabung karena daya beli yang dimiliki cukup tinggi.

\section{Opini Tentang Kesadaran (Awareness) Konsumen Roti}

Menurut Kotler dan Amstrong (2005), kesadaran (Awareness) pada proses adopsi produk baru adalah pelanggan menyadari adanya suatu produk tetapi masih kekurangan informasi mengenai produk tersebut.

Tabel 1. Merek Roti yang Ada di Dalam Pikiran Konsumen di Kota Bengkulu

\begin{tabular}{lcccccc}
\hline \multirow{2}{*}{$\begin{array}{c}\text { Merek } \\
\text { Roti }\end{array}$} & \multicolumn{2}{c}{$\begin{array}{c}\text { Pernyataan } \\
\text { Pertama }\end{array}$} & \multicolumn{2}{c}{\begin{tabular}{c} 
Pernyataan \\
\multicolumn{2}{c}{ Kedua }
\end{tabular}} \\
\cline { 2 - 7 } & $\begin{array}{c}\text { Jumlah } \\
\text { (Jiwa) }\end{array}$ & $\%$ & $\begin{array}{c}\text { Jumlah } \\
\text { (Jiwa) }\end{array}$ & $\%$ & $\begin{array}{c}\text { Jumlah } \\
\text { (Jiwa) }\end{array}$ & $\%$ \\
\hline Surya & 32 & 47,05 & 18 & 26,47 & 50 & 36,76 \\
Bake & 15 & 20,05 & 24 & 34,29 & 39 & 28,67 \\
Mart & 6 & 8,82 & 5 & 7,35 & 11 & 8,08 \\
Karina & 3 & 4,41 & 1 & 1,47 & 4 & 2,94 \\
Ais & 12 & 17,64 & 20 & 29,41 & 32 & 23,52 \\
\hline Jumlah & 68 & 100 & 68 & 100 & 136 & 100 \\
\hline
\end{tabular}

Sumber : Data Primer diolah (2012)

Berdasarkan Tabel 1, memberikan gambaran bahwa merek roti Surya Bakery adalah merek roti yang paling banyak diingat oleh pelanggan yang dibuktikan dengan persentase tertinggi yaitu 47,05\%, diikuti oleh merek roti Bake Mart yang lebih banyak diingat oleh pelanggan dengan persentase tertinggi 34,29\%. Secara keseluruhan dapat diketahui bahwa merek roti yang paling banyak diingat oleh konsumen roti di Kota Bengkulu adalah merek roti Surya Bakery dengan persentase tertinggi, yaitu sebesar 36,76\%.

Dalam hal ini, merek roti Surya Bakery merupakan pemimpin pasar dalam memikat hati pelanggan dengan banyaknya konsumen yang mengingat toko rotinya, disusul oleh pesaing pasar terberatnya yakni merek roti Bake Mart. Dengan demikian dapat dinyatakan bahwa toko roti Surya Bakery lebih dikenal oleh konsumen. Hal ini merupakan kekuatan bagi industri roti, oleh karena itu industri roti Surya Bakery harus dapat mempertahankan produknya tetap dikenal oleh konsumen.

\section{Opini Tentang Ketertarikan/minat (Interest) Konsumen Roti}

Pada pernyataan terhadap sikap konsumen konsumen roti akan melakukan seleksi, produk mana yang akan menjadi alternatif untuk dicoba. Konsumen roti yang ada di Kota Bengkulu memilih rasa yang manis menjadi hal 
yang paling diperhatikan, ini terlihat dari persentase sebanyak 52,94\%. Disusul dengan ukuran roti yang besar dengan persentase sebesar 33,82\%. Hal ini sangat menarik, karena konsumen roti tidak mempermasalahkan harga roti yang ditawarkan oleh pemilik toko roti, ini menunjukkan Kota Bengkulu sedang berkembang menjadi Kota yang sedang berkembang perekonomiannya. Lebih lanjut, sebanyak $42,64 \%$ konsumen memperhatikan kehalalan roti yang akan dikonsumsinya, karena mayoritas penduduk Kota Bengkulu merupakan muslim. Ini sebaiknya dijadikan acuan bagi pengusaha roti yang ada untuk memberikan tanda halal pada tiap-tiap kemasan rotinya.

Tabel 2 Kebutuhan Roti yang Diinginkan Konsumen Roti (Product Mix)

\begin{tabular}{lcr}
\hline \multicolumn{1}{c}{ Kebutuhan yang diinginkan } & Jumlah (Jiwa) & $\%$ \\
\hline Rasa roti yang manis & 36 & 52,94 \\
Ukuran roti yang besar & 23 & 33,82 \\
Bentuk roti yang menarik & 5 & 7,35 \\
Harga yang murah & 4 & 5,88 \\
\hline \multicolumn{1}{c}{ Jumlah } & 68 & 100 \\
\hline
\end{tabular}

Sumber : Data Primer diolah (2012)

Tabel 3 Roti yang Baik Dikonsumsi Menurut Konsumen Roti

\begin{tabular}{lcr}
\hline Penilain konsumen tentang roti yang baik & Jumlah (Jiwa) & $\%$ \\
\hline Roti yang memperhatikan kehalalan & 29 & 42,64 \\
Roti yang memperhatikan kualitasnya & 13 & 19,11 \\
Roti yang memperhatikan mutu & 4 & 5,88 \\
Roti yang memperhatikan kebersihan & 3 & 4,41 \\
Semuanya benar & 19 & 27,94 \\
\hline Jumlah & 68 & 100,00 \\
\hline
\end{tabular}

Sumber : Data Primer diolah (2012)

\section{Opini Tentang Percobaan (Experience) Roti oleh Konsumen}

Pada tahap percobaan produk, pelanggan mencoba suatu produk untuk menyempurnakan penilaian dan kemudian memutuskan untuk memakai produk tersebut secara tetap (Kotler,2005).

158 | Gracia Gabrienda, Nusril, Redy Badrudin. Analisa Orientasi Pasar ... 
Tabel 4. Merek Roti yang Sekarang sedang Dikonsumsi dan Terakhir dibeli oleh Konsumsen Roti

\begin{tabular}{lcccccc}
\hline \multirow{2}{*}{ Merek Roti } & \multicolumn{2}{c}{$\begin{array}{c}\text { Pernyataan } \\
\text { Pertama }\end{array}$} & \multicolumn{2}{c}{$\begin{array}{c}\text { Pernyataan } \\
\text { Kedua }\end{array}$} & \multicolumn{2}{c}{$\begin{array}{c}\text { Pernyataan } \\
\text { Ketiga }\end{array}$} \\
\cline { 2 - 7 } & $\begin{array}{c}\text { Jumlah } \\
\text { (Jiwa) }\end{array}$ & $\%$ & $\begin{array}{c}\text { Jumlah } \\
\text { (Jiwa) }\end{array}$ & $\%$ & $\begin{array}{c}\text { Jumlah } \\
\text { (Jiwa) }\end{array}$ & $\%$ \\
\hline Surya & 39 & 57,35 & 37 & 54,41 & 76 & 55,88 \\
Bake Mart & 22 & 32,35 & 14 & 20,58 & 36 & 26,47 \\
Karina & 3 & 4,41 & 5 & 7,35 & 8 & 5,88 \\
Ais & 1 & 1,47 & 2 & 2,94 & 3 & 2,20 \\
Lainnya & 3 & 4,41 & 10 & 14,70 & 13 & 9,55 \\
\hline Jumlah & 68 & 100 & 68 & 100 & 136 & 100 \\
\hline
\end{tabular}

Sumber : Data Primer diolah (2012)

Hasil penelitian menunjukkan bahwa merek roti Surya Bakery adalah merek roti yang sekarang sedang dikonsumsi oleh masyarakat saat ini, yakni dengan persentase sebanyak 57,35\%. Menyusul toko roti Bake Mart dengan persentase $32,35 \%$ konsumen yang sedang mengkonsumsi rotinya.Hal ini menunjukkan bahwa merek roti Surya Bakery dan Bake Mart banyak digemari oleh konsumen roti yang ada di Kota Bengkulu. Sedangkan untuk pernyataan kedua yang menanyakan merek roti yang terakhir dikonsumsi oleh konsumen roti dapat diketahui bahwa persentase tertinggi untuk merek roti yang dikonsumsi sebelum merek terakhir yaitu merek roti Surya Bakery sebesar $54,41 \%$.

Dari tabel 4 di atas, jelas terlihat bahwa Surya Bakery merupakan merek yang paling banyak dikonsumsi baik sebagai roti yang sekarang sedang dikonsumsi maupun sebagai merek yang terakhir dibeli oleh konsumen roti. Hal ini menunjukkan bahwa tidak terjadinya pergeseran konsumsi dari produk roti Surya Bakery ke produk roti merek lain, artinya konsumen cukup loyal terhadap roti Surya Bakery sebagai produk yang disukai oleh konsumen. Hal ini merupakan kekuatan dalam merebut pelanggan pasar kompetitor. Lebih lanjut, Tabel 4 juga menginformasikan kedudukan pasar masing-masing toko roti. Toko roti Surya Bakery dengan 55,88\% nya sudah sangat memadai untuk menjadi pemimpin pasar dalam hal toko roti yang sekarang sedang dikonsumsi dan terakhir dibeli. Disusul oleh pesaing pasarnya, yakni toko roti Bake Mart dengan 26,47\%. Sedangkan untuk toko roti Karina Bakery dan Ais Bakery, masing-masing berada di Pengikut pasar dan perelung pasar.

\section{Kedudukan (posisi) Perusahaan di Pasar Pesaing}

Posisi pasar dalam penelitian ini dapat dilihat dari jumlah pendapatan yang diterima oleh setiap perusahaan roti yang menjadi subject penelktian ini. Hasil survai didapatkan bahwa Toko roti Surya Bakery dengan $50 \%$ penguasaan pasarnya menempati pemimpin pasar. Bake Mart dengan persentase sebesar $30 \%$ sudah memenuhi syarat untuk menempati posisi pesaing pasar. Sebesar 
$15 \%$ yang dimiliki toko roti Karina, menempatkannya di posisi pengikut pasar. Ais Bakery menempati posisi terakhir sebagai perelung pasar dengan 5\% pendapatanya dibandingkan dengantoko roti lainnya.

Tabel 5 Pendapatan Toko Roti menurut Posisi Pasarnya

\begin{tabular}{lcc}
\hline \multicolumn{1}{r}{ Merek Roti } & Pendapatan per Bulan (Rp. Juta) & Persentase \\
\hline Surya & 150 & 50 \\
Bake Mart & 90 & 30 \\
Karina Bakery & 45 & 15 \\
Ais Bakery & 150 & 5 \\
\hline \multicolumn{1}{c}{ Total } & 300 & 100 \\
\hline
\end{tabular}

Sumber : Data Primer diolah (2012)

\section{Orientasi Pasar Produsen-produsen Roti di Kota Bengkulu}

Dari posisi pasar yang telah dibahas diatas, maka dapat dilihat bahwa orientasi pasar ke-4 toko roti ini adalah orientasi pelanggan. Orientasi pelanggan ini maksudnya ialah toko roti tersebut lebih mengutamakan pelanggannya dibandingkan dengan pesaing-pesaingnya. Ini bisa terlihat dari semakin gencarnya toko roti ini meningkatkan penjualan rotinya dan menambah beberapa outlet untuk memperluas penjualan pangsa pasarnya, serta sistem distribusi lainnya.

Toko roti-toko roti ini lebih terfokus untuk menambah jumlah konsumennya dari hari ke hari. Tidak hanya penambahan outlet untuk perluasan pangsa pasar saja, tetapi dari produk yang dihasilkan pun semakin lebih baik dari sebelumnya. Kemasan untuk tiap-tiap roti, variasi roti yang kian banyak, pelayanan yang baik yang dilakukan oleh karyawan toko, fasilitas yang diciptakan pemilik toko roti untuk kenyamanan pelanggan, seperti adanya Air Conditioner, lahan parkir yang memadai, dan lain sebagainya.

\section{Formulasi Strategi Bauran Pemasaran (Marketing Mix) 4P Pengusaha Roti}

Dari hasil penelitin, alternatif strategi bauran pemasaran roti pada toko roti Surya Bakery, Bake Mart, Karina Bakery dan Ais Bakery dapat dijelaskan sebagai berikut:

\section{A. Surya Bakery}

Strategi bauran pemasaran yang bisa dilakukan oleh toko roti Surya Bakery, umumnya dengan mengembangkan strategi:

1. Mengembangkan pasar keseluruhan, hal ini dapat dilakukan dengan cara: (i) Mencari konsumen baru dengan cara strategi penerobosan pasar, strategi pasar baru, dan strategi perluasan geografis, (ii) Mencari dan mengenalkan kegunaan suatu produk, dan (iii) 
Meyakinkan masyarakat konsumen agar menggunakan produk lebih banyak pada setiap kesempatan

2. Melindungi bagian-bagian pasar yang telah dikuasai. Sementara mencoba memperkuat pasar, perusahaan yang dominan tetap harus melindungi usahanya secara terus menerus dari serangan saingansaingannya. Untuk itu yang harus dikerjakan oleh perusahaan pemimpin dalam mempertahankan daerah kekuasaannya adalah inovasi yang terus menerus. Meningkatkan bagian pasar, selain mencari konsumen baru pada pasar yang baru perusahaan juga dapat meningkatkan jumlah konsumen pada bagian pasar yang sudah dikuasai.

\section{B. Bake Mart}

Strategi bauran pemasaran yang bisa dilakukan oleh toko roti Bake Mart, umumnya dengan melakukan beberapa strategi penyerangan yang bisa digunakan, yakni (a) Menetapkan sasaran strategi lawan, dan (b) Memilih strategi penyerangan.

Secara umum ada lima strategi penyerangan yang dapat dipilih dan dilakukan market challanger: (i) Serangan frontal. (ii) Serangan melambung, (iii) Serangan mengepung, (iv) Serangan lintas, dan (v) Serangan gerilya. Selain ke lima strategi penyerangan secara umum tersebut, terdapat strategi yang lebih spesifik lagi bagi Market Challanger yaitu: (i) Strategi pemotongan harga, (ii) Strategi produk yang lebih murah, (iii) Strategi produk prestise, (iv) Strategi pengembang biakan produk, (v) Strategi inovasi produk, (vi) Strategi penyempurnaan jasa pelayanan, (vii) Strategi inovasi distribusi, (viii) Strategi penekanan biaya, serta (ix) Strategi promosi yang intensif.

\section{Karina Bakery}

Strategi bauran pemasaran yang umumnya dilakukan oleh Market Follower, yaitu: (a) Mengikuti dari dekat, (b) Mengikuti dari jauh, dan (c) Mengikuti secara selektif.

\section{Ais Bakery}

Strategi bauran pemasaran yang bisa dilakukan oleh toko roti Ais Bakery sebagai Market Nicher, yakni dengan mencoba masuk kesatu atau lebih celahcelah pasar yang aman dan menguntungkan yang dilupakan atau terlewatkan oleh perusahaan besar. Umumnya Market Nicher adalah perusahaan yang mempunyai spesialisasi tertentu dan keahlian yang khas didalam pasar, konsumen, produk atau lini-lini dalam bauran pemasaran. 


\section{SIMPULAN DAN SARAN}

\section{Simpulan}

Berdasarkan hasil penelitian, dapat disimpulkan bahwa:

1. Posisi pasar pengusaha-pengusaha roti yang ada di Kota Bengkulu:

a. Market Leader : Surya Bakery dengan 50\% total pendapatan ke empat toko roti

b. Market Challenger : Bake Mart dengan 30\% total pendapatan ke empat toko roti

c. Market Follower : Karina Bakery dengan 15\% total pendapatan ke empat toko roti

d. Market Nicher : Ais Bakery dengan $5 \%$ total pendapatan ke empat toko roti

2. Orientasi pasar yang dilakukan keempat toko roti ini ialah orientasi yang bertuju kepada pelanggannya, ini terlihat dari semakin berkualitasnya roti yang dipasarkan dan semakin bervariasi rasa dan bentuknya, ini semata dilakukan untuk memuaskan pelanggan.

3. Formulasi strategi bauran pemasaran untuk tiap-tiap toko roti:

a. Surya Bakery: memperluas pasar dan menginsifkan promosi.

b. Bake Mart : perluasan jaringan distribusi.

c. Karina Bakery: menonjolkan sifat khas toko rotinya.

d. Ais Bakery : mencari celah pemasaran yang belum dimasuki pesaing.

\section{Saran}

1. Sebaiknya toko roti Surya Bakery mempromosikan produknya melalui media yang ada, seperti televisi lokal, radio dan koran agar lebih dikenal oleh masyarakat di Kota Bengkulu dan diluar Kota Bengkulu untuk memperluas pasar yang telah dimiliki

2. Sebaiknya toko roti Bake Mart, memperluas jaringan distribusi dari yang telah dimiliki saat ini.

3. Sebaiknya toko roti Karina Bakery memberikan suatu cirri khas, baik dari toko rotinya maupun produk rotinya, untuk mempertahankan pelanggan yang sudah ada.

4. Sebaiknya toko roti Ais Bakery mendistribusikan produk rotinya ke pasarpasar yang terlewatkan oleh pesaing-pesaingnya, dari cara ini konsumen bisa mengenal dan menyukai produk roti dari Ais Bakery. 


\section{DAFTAR PUSTAKA}

Anonim. 2009. Dibalik Empuknya Roti. http://www.halalguide.info/ 2009/04/27/ dibalik-empuknya-roti/. (Diakses 27 Februari 2011).

Anonim. 2011. Pengertian Roti. http://id.wikipedia.org/wiki/Roti. (Diakses 27 Februari 2011).

BPS. 2008. Provinsi Bengkulu Dalam Angka. Bengkulu.

Irawan, M. 2005. Analisis Strategi Pemasaran Minuman Teh Botol Pada Industri Rumah Tangga Teh Tour di Kota Bengkulu. Skripsi Jurusan Sosial Ekonomi Pertanian, Fakultas Pertanian, Universitas Bengkulu (tidak dipublikasikan).

Kotler, P. dan Gary A. Amstrong. 1995. Manajemen Pemasaran (Analisis, Perencanaan, Implementasi, dan Pengendalian). Salemba Empat . Jakarta.

Winardi, O. 1981. Manajemen Pemasaran. Sinar Baru.Bandung. 